\title{
Nutritional quality of chestnut (Castanea sativa Mill.) cultivars from Portugal
}

\author{
Olga Borges ${ }^{\mathrm{a}}$, Berta Gonçalves ${ }^{\mathrm{b}}$, José L. Soeiro de Carvalho ${ }^{\mathrm{a}}$, \\ Paula Correia $^{\mathrm{c}}$, Ana Paula Silva ${ }^{\mathrm{d}, *}$ \\ ${ }^{\text {a }}$ DRAPN - Direç̧ão Regional de Agricultura e Pescas do Norte, Quinta do Valongo, Carvalhais, 5370-087 Mirandela, Portugal \\ ${ }^{\mathrm{b}}$ CETAV - Centre for Technological, Environmental and Life Studies, Department of Biological and Environmental Engineering, \\ University of Trás-os-Montes e Alto Douro, Apartado 1013, 5001-801 Vila Real, Portugal \\ ${ }^{\mathrm{c}}$ Agrarian School of Viseu, Quinta da Alagoa, Estrada de Nelas, Ranhados, 3500-606 Viseu, Portugal \\ ${ }^{\mathrm{d}}$ CECEA - Research Centre for Agricultural Sciences and Engineering, Department of Plant Science and Agricultural Engineering, \\ University of Trás-os-Montes e Alto Douro, Apartado 1013, 5001-801 Vila Real, Portugal
}

Received 15 January 2007; received in revised form 18 May 2007; accepted 5 July 2007

\begin{abstract}
Chemical composition of eight sweet chestnut cultivars from the three protected designation of origin (PDO) areas in the Trás-osMontes region were studied: Aveleira, Rebordã, Trigueira and Zeive from PDO 'Terra Fria', Demanda, Longal and Martaínha from PDO 'Soutos da Lapa' and Judia from PDO 'Padrela'. Chestnuts were characterised by high moisture content ( $\sim 50 \%)$, high levels of starch (43 g $100 \mathrm{~g}^{-1}$ dry matter - d.m.) and low fat content $\left(3 \mathrm{~g} 100 \mathrm{~g}^{-1}\right.$ d.m.). Nuts contained significant amounts of fibre (3\%

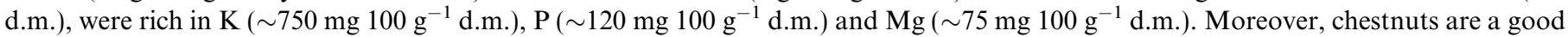

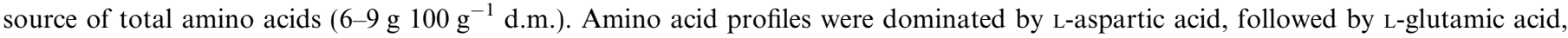
leucine, L-alanine and arginine. These results provide additional information about the nutritional value of each cultivar and confirm that chestnuts are an interesting healthy food.
\end{abstract}

(c) 2007 Elsevier Ltd. All rights reserved.

Keywords: Castanea sativa; Proximate analysis; Fibre; Minerals; Amino acids; Chemical composition

\section{Introduction}

Populations with a typical Mediterranean diet, characterised by a low consumption in meat and a high consumption in fish, fruits and vegetables and having nuts as valuable compounds, present lower mortality rates from coronary heart disease and cancer (Sabaté, Radak, \& Brown, 2000). An increasing amount of evidence shows that the consumption of fruits, particularly nuts, has become more important in human nutrition, due to the protection provided by the antioxidant compounds (Blom-

\footnotetext{
${ }^{*}$ Corresponding author.

E-mail address: asilva@utad.pt (A.P. Silva).
}

hoff, Carlsen, Andersen, \& Jacobs, 2006). According to these authors, of the tree nuts, chestnuts, walnuts and pecans have the highest content of antioxidants. Therefore, in recent years, the consumers have been showing an increased interest in chestnut fruits because of their nutritional qualities and potential beneficial health effects. In fact, chestnuts are also rich in carbohydrates and are a good source of essential fatty acids and minerals (Desmaison \& Adrian, 1986; Senter, Payne, Miller, \& Anagnostakis, 1994; Ferreira-Cardoso, Rodrigues, Gomes, Sequeira, \& Torres-Perreira, 1999; Künsch et al., 1999; Borges, Carvalho, Correia, \& Silva, 2006). In addition, they present several vitamins and appreciable levels of fibre (Vaughan \& Geissler, 1997). 
Chestnut (Castanea sativa Mill.) is one of the oldest edible fruits in Portugal and, in the past, was widely used as extensively as potato and most of the tubers (FerreiraCardoso et al., 1999). The mainly production area is located in the Trás-os-Montes region (Northeast of Portugal), with an important role in the economy and landscape patrimony, contributing with $84 \%$ of the total of Portuguese's production. In order to preserve the biological material and to improve its cultivation, in 1994 three protected designation of origin (PDO) called 'Castanha da Terra Fria', 'Castanha dos Soutos da Lapa' and 'Castanha da Padrela' were created. In each PDO, with different environmental conditions, there are many well-adapted native cultivars. Since information about the nutritional composition of the Portuguese chestnut cultivars from the three PDO areas is still limited, the aim of this work was to determine starch, reductor sugars, crude protein, crude fat, fibre, mineral content and amino acid concentration of eight important native cultivars. This study also provides a useful reference about the quality of each cultivar for fresh market and industrial processing and also for producers and breeders.

\section{Materials and methods}

\subsection{Samples}

From the protected designation of origin (PDO) in the Trás-os-Montes region were chosen eight of the most important chestnut native cultivars: Aveleira, Rebordã, Trigueira and Zeive from PDO 'Terra Fria', Demanda, Longal and Martaínha from PDO 'Soutos da Lapa' and Judia from PDO 'Padrela'. Each PDO area has specific environmental conditions (Table 1). In the 2005 chestnut ripening season three representative trees from each cultivar were selected. Three samples $(1 \mathrm{~kg}$ of nuts per sample) of each selected tree were randomly collected and kept unshelled in a refrigerator $\left(2{ }^{\circ} \mathrm{C}\right)$ until analyses were performed $(n=9)$. Each sample was analysed in triplicate.

Table 1

Geographic and soil characterisation of the three protected designation of origin $(\mathrm{PDO})^{\mathrm{a}}$

\begin{tabular}{|c|c|c|c|c|}
\hline DOP & $\begin{array}{l}\text { Altitude } \\
\text { (m) }\end{array}$ & Latitude & Longitude & Soill $^{\mathrm{a}}$ \\
\hline 'Terra Fria' & $650-900$ & $41^{\circ} 40^{\prime}-41^{\circ} 55^{\prime} \mathrm{N}$ & $6^{\circ} 50^{\prime}-7^{\circ} 10^{\prime} \mathrm{W}$ & $\begin{array}{l}\text { Distric } \\
\text { cambisols } \\
\text { from schists }\end{array}$ \\
\hline 'Soutos da Lapa' & $700-800$ & $40^{\circ} 59^{\prime}-41^{\circ} 05^{\prime} \mathrm{N}$ & $7^{\circ} 25^{\prime}-7^{\circ} 50^{\prime} \mathrm{W}$ & $\begin{array}{l}\text { Distric } \\
\text { cambisols } \\
\text { from } \\
\text { granites }\end{array}$ \\
\hline 'Padrela' & $800-900$ & $41^{\circ} 35^{\prime}-41^{\circ} 35^{\prime} \mathrm{N}$ & $7^{\circ} 24^{\prime}-7^{\circ} 30^{\prime} \mathrm{W}$ & $\begin{array}{l}\text { Humic } \\
\text { umbrisols } \\
\text { from granits }\end{array}$ \\
\hline
\end{tabular}

\footnotetext{
${ }^{\text {a }}$ According to the soil map region and the correspondence to the World reference base for soil resources (FAO, 1998).
}

\subsection{Proximate analysis}

Moisture content was determined using the AOAC method (AOAC, 1990) and ash content according to AOAC (2000). Starch content was determined by a polarimetric method (Garcia \& Wolf, 1972). Reductor sugars were determined according to AOAC (2000). The total nitrogen content was detected using the Kjeldahl method and the percentages of nitrogen were transformed into protein content by multiplying by a conversion factor of 5.3 (AOAC, 2000). The total fat extraction was performed according to AOAC (2000) methodology, using a Soxhlet apparatus; petroleum ether was used for extraction during $16 \mathrm{~h}$. Chestnuts were shelled before analysis.

\subsection{Mineral analysis}

Macro and micronutrients $\mathrm{K}, \mathrm{Ca}, \mathrm{Mg}, \mathrm{Cu}, \mathrm{Fe}, \mathrm{Mn}, \mathrm{Na}$ and $\mathrm{Zn}$ were determined by atomic absorption using a spectrophotometer model SP9 Unilamp (AOAC, 2000) and $\mathrm{P}$ was estimated using a UV spectrophotometer model Hitachi U-2000 (BOE, 1995).

\subsection{Fibre analysis}

Crude fibre (CF), acid detergent and neutral fibre (ADF and NDF, respectively) were evaluated after extraction with the neutral detergent solution hydrolysis according to the procedures described by Van Soest and Wine (1967) using a Dosi-fibre with six plates, code 4000623, J.P. Selecta, S.A.

\subsection{Total free $\alpha$-amino acids analysis}

The extraction and purification of free $\alpha$-amino acids were performed according to Stein and Moore (1978). Dry chestnut flour $(0.3 \mathrm{~g})$ was weighed into a volumetric flask with $50 \mathrm{ml}$ of $\mathrm{HCl} 6 \mathrm{M}$, containing $1 \mathrm{~g}^{-1}$ reagent grade phenol and $5000 \mathrm{nmol}$ of norleucine as an internal standard. Following removal of the acid at $50^{\circ} \mathrm{C}$ on a rotary evaporator, the hydrolysates were transferred to an Erlenmyer flask and the volume was completed with distilled filtered water (Spartan 13, $0.2 \mu \mathrm{m}$ ). Two $\mathrm{ml}$ of this solution was centrifuged for $2 \mathrm{~min}$ at $5000 \mathrm{rpm}$. The dried residue was dissolved in $5 \mathrm{ml}$ sodium citrate buffer, pH 2.2 (Amersham Pharmacia Biotech AB). The resuspended solution was filtered and kept at $-80^{\circ} \mathrm{C}$ until quantification. After that, suitable aliquots were analysed by ionic-exchange chromatography (in an automatic amino acid analyser Biochrom 20, Amersham Pharmacia Biotech $\mathrm{AB}$ ), using the standard protein hydrolysate program with sodium citrate buffer and ninhydrin detection (Amersham Pharmacia Biotech AB). Afterwards, they were detected at 440 and $570 \mathrm{~nm}$, with a spectrophotometer incorporated in the analyser equipment. Identification and quantification of detected amino acids were done comparing the calibration curves, through a data acquisi- 
tion and treatment Ezchrom TM Chromatography Data System, version 6.7 .

\subsection{Statistical analysis}

Data analyses were performed as analysis of variance using the Super ANOVA software (1.1, Abacus Concepts Inc., 1991). Mean separations were made using Fisher's protected LSD test $(P<0.05)$, designed to allow all possible linear combination of group means to be test.

A Fisher correlation analysis and a principal component analysis (PCA) including several of the studied parameters were also performed using the Stat View 4.0 package.

\section{Results and discussion}

\subsection{Proximate analysis}

Results obtained for proximate composition of the eight chestnut cultivars are shown in Table 2. Moisture was the predominant component and showed significant differences among all the cultivars $(P<0.001)$. The average moisture content was $51 \%$, close to the mean value $(53 \%)$ referred to Desmaison and Tixier (1984) for several French cultivars from C. sativa (e.g., Belle Epine, Sardonne, Bouche Rouge) and Castanea crenata (Malemort, Sapporo) but higher than cultivars from Castanea mollissima. Cv. Demanda from PDO 'Soutos da Lapa' showed the highest moisture value (53\%), whilst the cv. Rebordã PDO 'Terra Fria' showed the lowest $(46 \%)$. On average, this region produced nuts with the lowest moisture content. This behaviour was probably due to the soil genesis: the PDO 'Soutos da Lapa' has developed from granites and PDO 'Terra Fria' from schist and basic rocks, which affects the root zone aeration and the tree water potential. Furthermore, Pereira-Lorenzo, Ramos-Cabrer, Díaz-Hernández, Ciordia-Ara, and RiosMesa (2005) found a significant effect of the geographical origins on the moisture content of the 47 Spanish cultivars. In fact, the highest moisture content (56\%) was presented by the cultivars from the Northern regions (Asturias, Gali- cia and Castilla-León), when comparing with the cultivars (mean 51\%) from the South (Andaluzia), due to the low summer rainfall.

The chemical composition of the chestnuts reveals high levels of starch, the predominant component of dry matter (Table 2). Künsch et al. (1999) recognised these fruits as an excellent source of starch and found higher values than potatoes, wheat and walnuts. The analysis of variance showed that cultivar had a significant effect on starch content $(P<0.001)$, ranged from $39 \mathrm{~g} 100 \mathrm{~g}^{-1} \mathrm{~d} . \mathrm{m}$. in cv. Judia (PDO 'Padrela') and $48 \mathrm{~g} 100 \mathrm{~g}^{-1}$ d.m. in cv. Zeive (PDO 'Terra Fria'). Average starch content of these culti-

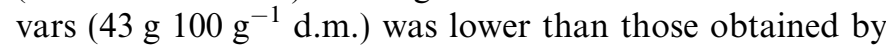
Pereira-Lorenzo et al. (2005), which presented $57 \mathrm{~g}$ $100 \mathrm{~g}^{-1} \mathrm{~d}$.m. as the mean value for the Spanish cultivars,

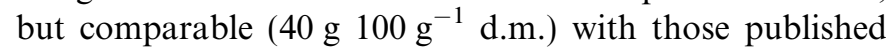
by McCarthy and Meredith (1988) for C. sativa and

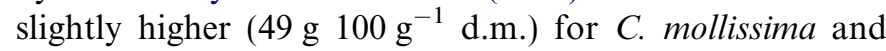
$C$. dentata. Nevertheless, De La Montaña Míguelez, Míguez Bernárdez, and Garcia Queijeiro (2004) found that the starch content varied between 56.7 and $81.7 \mathrm{~g}$ $100 \mathrm{~g}^{-1} \mathrm{~d}$.m. from the 15 most wide spread varieties of C. sativa growing in the Galician region Verín-Monterrei (Ourense). Studies carried out by Ferreira-Cardoso (2000) with cvs. Longal (PDO 'Terra Fria'), Aveleira (PDO 'Terra Fria') and Judia showed values around 10-20\% higher. Probably, this variation reflects the high dependence of starch concentration with the environmental factors and growing conditions.

As we all know, studies on starch content are essential for their best use in the food industry, flour production or for animal feed (Demiate, Oetterer, \& Wosiacki, 2001). During storage the starch is partially hydrolysed into monosaccharide, which gives sweetness to the chestnuts (Pereira-Lorenzo et al., 2005; Ertürk, Cevriye, \& Arif, 2006). High contents of starch and moisture are important to the fresh market but are responsible for the development of mould, which decreases the storage life.

Crude protein varied significantly among cultivars $(P<0.001)$. Cv. Aveleira $\left(4.9 \mathrm{~g} 100 \mathrm{~g}^{-1}\right.$ d.m. $)$ and all the

Table 2

Proximate composition of the eight chestnut cultivars

\begin{tabular}{|c|c|c|c|c|c|c|c|}
\hline PDO & Cultivar & Moisture (\%) & $\begin{array}{l}\text { Starch } \\
\left(\mathrm{g} 100 \mathrm{~g}^{-1} \text { d.m. }\right)\end{array}$ & $\begin{array}{l}\text { Crude protein } \\
\left(\mathrm{g} 100 \mathrm{~g}^{-1} \text { d.m. }\right)\end{array}$ & $\begin{array}{l}\text { Reductor sugars } \\
\text { (g } 100 \mathrm{~g}^{-1} \text { d.m.) }\end{array}$ & $\begin{array}{l}\text { Crude fat } \\
\left(\mathrm{g} 100 \mathrm{~g}^{-1} \text { d.m.) }\right.\end{array}$ & $\begin{array}{l}\text { Ash } \\
\text { (g } 100 \mathrm{~g}^{-1} \text { d.m.) }\end{array}$ \\
\hline 'Padrela' & Judia & $52.9 \pm 0.8 \mathrm{c}$ & $38.6 \pm 1.2 \mathrm{a}$ & $5.40 \pm 0.20 \mathrm{~b}$ & $3.10 \pm 0.20 \mathrm{c}$ & $2.63 \pm 0.06 \mathrm{de}$ & $1.90 \pm 0.10 \mathrm{bcd}$ \\
\hline 'Terra Fria' & $\begin{array}{l}\text { Aveleira } \\
\text { Rebordã } \\
\text { Trigueira } \\
\text { Zeive } \\
P\end{array}$ & $\begin{array}{l}49.9 \pm 1.6 \mathrm{~b} \\
46.3 \pm 0.9 \mathrm{a} \\
47.4 \pm 1.7 \mathrm{a} \\
51.6 \pm 2.6 \mathrm{bc} \\
<0.001\end{array}$ & $\begin{array}{l}42.9 \pm 1.1 \mathrm{bc} \\
44.3 \pm 1.3 \mathrm{~cd} \\
46.0 \pm 1.4 \mathrm{de} \\
47.9 \pm 1.5 \mathrm{e} \\
<0.001\end{array}$ & $\begin{array}{l}4.87 \pm 0.12 \mathrm{a} \\
5.60 \pm 0.17 \mathrm{~b} \\
5.30 \pm 0.27 \mathrm{~b} \\
5.50 \pm 0.10 \mathrm{~b} \\
<0.001\end{array}$ & $\begin{array}{l}2.37 \pm 0.57 \mathrm{~b} \\
1.77 \pm 0.15 \mathrm{a} \\
3.27 \pm 0.15 \mathrm{~cd} \\
3.20 \pm 0.06 \mathrm{~cd} \\
<0.001\end{array}$ & $\begin{array}{l}2.57 \pm 0.06 \mathrm{~cd} \\
1.73 \pm 0.06 \mathrm{a} \\
2.60 \pm 0.00 \mathrm{~cd} \\
2.73 \pm 0.06 \mathrm{e} \\
<0.001\end{array}$ & $\begin{array}{l}1.53 \pm 0.21 \mathrm{a} \\
2.20 \pm 0.20 \mathrm{~d} \\
1.83 \pm 0.06 \mathrm{abc} \\
2.20 \pm 0.20 \mathrm{~d} \\
<0.01\end{array}$ \\
\hline
\end{tabular}

Values are average of three individual samples per tree each analysed in triplicate \pm SD.

Different letters within one column denote statistically significant differences $(P<0.05)$ by ANOVA and Fisher's LSD test.

Statistical significance: ${ }^{*} P<0.05 ;{ }^{* *} P<0.01$; and ${ }^{* * *} P<0.001$ by Fisher's test. 
cvs. from PDO 'Terra Fria' showed the lowest values, whilst cvs. from PDO 'Soutos da Lapa' presented the

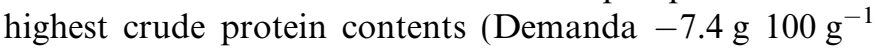
d.m.). Pereira-Lorenzo et al. (2005) founded similar pro-

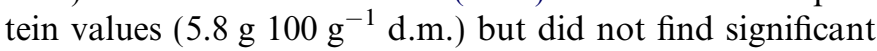
variations among the 47 Spanish cultivars or the six regions studied. Moreover, cv. Longal presented exactly

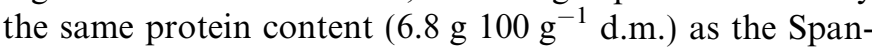
ish Longal in accordance with De La Montaña Míguelez et al. (2004). Analogous trends were found for reductor sugars, i.e., cv. Rebordã contained the lowest value $\left(1.8 \mathrm{~g}^{-100 \mathrm{~g}^{-1}} \mathrm{~d}\right.$.m.) and $\mathrm{cv}$. Longal the highest $(3.7 \mathrm{~g}$ $100 \mathrm{~g}^{-1}$ d.m.).

Crude fat content of all the samples ranged from 1.7 to

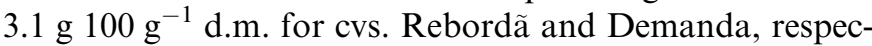
tively. These results are in accordance with those obtained by Desmaison and Adrian (1986) for French cultivars, Bassi and Marangoni (1984) for Italian cultivars, De La Montaña Míguelez et al. (2004) and Pereira-Lorenzo et al. (2005) for Spanish cultivars, and Ertürk et al. (2006) for C. sativa and hybrid cultivars. Due to the low fat content when compared with other nuts such almonds, hazelnuts and walnuts, chestnut has low caloric value, which makes it an interesting healthy food (Salas-Salvadó \& Megias, 2005).

Ash content is low in chestnuts changed between 1.5 (cv.

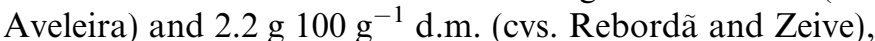

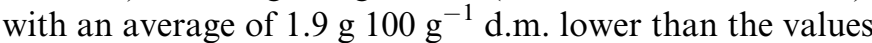
reported by Pereira-Lorenzo et al. (2005) and Ertürk et al. (2006).

\subsection{Minerals}

The contents of nine minerals were determined in the eight studied cultivars (Table 3 ). All of these nutrients varied significantly among cultivars. Concerning the macronutrients, $\mathrm{K}$ was the most abundant, changed from $473 \mathrm{in} \mathrm{cv}$. Martaínha (PDO 'Soutos da Lapa') to $974 \mathrm{mg} 100 \mathrm{~g}^{-1}$ d.m. in cv. Zeive, with $754 \mathrm{mg} 100 \mathrm{~g}^{-1}$ d.m. as a mean value. $P$ was the second mineral and varied between 104 in cv. Rebordã and $148 \mathrm{mg} 100 \mathrm{~g}^{-1}$ d.m. in cv. Demanda, with $123 \mathrm{mg} 100 \mathrm{~g}^{-1}$ d.m. as a mean value. $\mathrm{Mg}$ content ranged between 63 in cv. Trigueira and $93 \mathrm{mg} 100 \mathrm{~g}^{-1}$ d.m. in cv. Demanda, with $75 \mathrm{mg} 100 \mathrm{~g}^{-1} \mathrm{~d} . \mathrm{m}$. as a mean value. Chestnuts had low values of $\mathrm{Ca}$ ( $41 \mathrm{in} \mathrm{cv}$. Judia to $51 \mathrm{mg} 100 \mathrm{~g}^{-1}$ d.m. in cv. Rebordã), with $45 \mathrm{mg} 100 \mathrm{~g}^{-1}$ d.m. on average. Mean values are comparable with those published previously in the literature for European (Ferreira-Cardoso et al., 1999; Pereira-Lorenzo et al., 2005) and Chinese cultivars (McCarthy \& Meredith, 1988). In general, the cultivars from PDO 'Terra Fria', characterised by schist soils, showed high levels of macronutrients. In accordance, Parcerisa et al. (1995) stated that composition of soil, uses of fertilisers and irrigation affect the mineral composition of the hazelnuts.

With regard to micronutrients (Table 3 ), Fe was the most abundant ranged from $5.3 \mathrm{mg} 100 \mathrm{~g}^{-1}$ d.m. in cv.

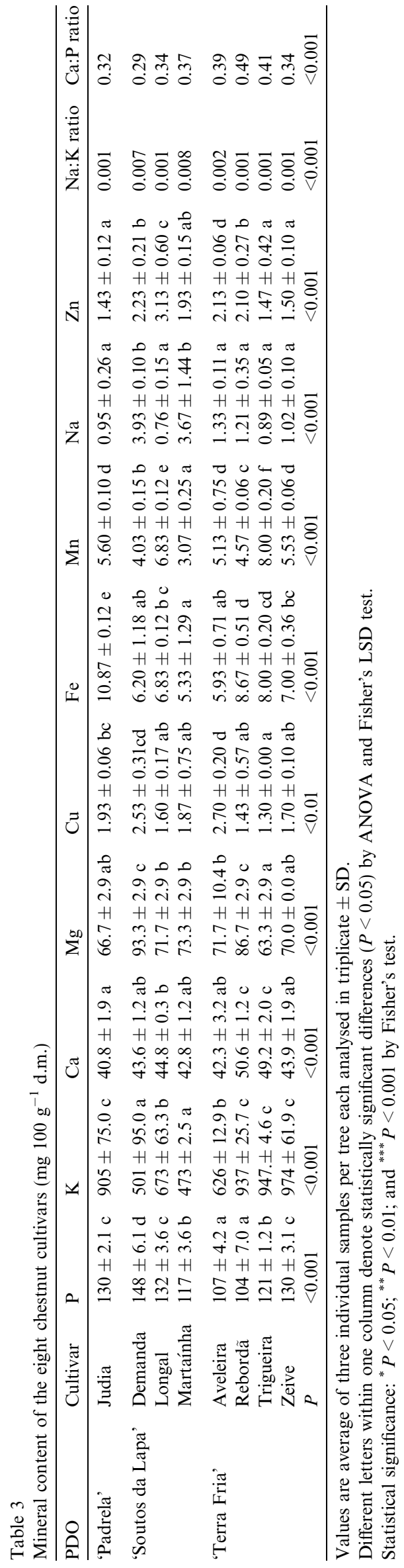


Martaínha to $10.9 \mathrm{mg} 100 \mathrm{~g}^{-1}$ d.m. in cv. Judia, followed by $\mathrm{Mn}\left(3.1100 \mathrm{~g}^{-1}\right.$ d.m. in cv. Martaínha to $8.0100 \mathrm{~g}^{-1}$ d.m. in cv. Trigueira - PDO 'Terra Fria'), Zn (1.4 $100 \mathrm{~g}^{-1}$ d.m. in cv. Judia to $3.100 \mathrm{~g}^{-1}$ d.m. in cv. Longal), and $\mathrm{Cu}\left(1.3 \mathrm{mg} 100 \mathrm{~g}^{-1}\right.$ d.m. in cv. Trigueira to $2.7 \mathrm{mg}$ $100 \mathrm{~g}^{-1}$ d.m. in cv. Aveleira). These data are slightly different from the values referenced in literature. Thus, while the Fe content was higher than the value reported in other studies (McCarthy \& Meredith, 1988; Portela, FerreiraCardoso, Reboredo, \& Pimentel-Pereira, 1999; Üstün, Tosun, \& Serdar, 1999; Ferreira-Cardoso, 2000) the Zn and $\mathrm{Cu}$ were lower (Portela et al., 1999). The level of $\mathrm{Mn}$ was higher when compared with the values obtained by McCarthy and Meredith (1988) and Ferreira-Cardoso (2000), and lower than the values reported by Portela et al. (1999) and Üstün et al. (1999).

Concerning human nutritional aspects, chestnuts have an important mineral content. The fruits are a good source of $\mathrm{K}, \mathrm{Mg}, \mathrm{Fe}, \mathrm{Mn}$ and $\mathrm{Cu}$. These minerals have many functions in the human organism: $K$ is associated with fluid balance and volume, carbohydrate metabolism, protein synthesis and nerve impulses; $P$ has an important role on mineralisation of bones and teeth, energy metabolism, absorption and transport of nutrients; $\mathrm{Mg}$ is important in nervous activity and muscle contraction (Diehl, 2002). However, excess of one mineral (e.g. K) could be antagonist for others to be absorbed. For this reason, ratios of the mineral constituents are important for good nutrition: $\mathrm{Na}: \mathrm{K}$ and $\mathrm{Ca}: \mathrm{P}$. A low $\mathrm{Na}: \mathrm{K}$ ratio (0.001) makes chestnuts interesting for diets with a defined electrolytic balance (Stamler, 1994). The mean $\mathrm{Ca}: \mathrm{P}$ ratio being 0.37 , reveals a high concentration of $\mathrm{P}$ compared to $\mathrm{Ca}$. This ratio should not be less than 1.0. Iqbal, Khalil, Ateeq, and Khan (2006) advice, when this occurs, a mineral supplementation as an alternative approach to correct this imbalance. In general, comparing the eight cultivars, the chestnuts from PDO 'Terra Fria' (schist soils) had the highest ratio (Table 3). However, according to Iqbal et al. (2006) these cultivars also need a mineral supplementation.

\subsection{Fibre}

Crude fibre $(\mathrm{CF})$ showed significant differences among cultivars $(P<0.001)$ like acid detergent fibre (ADF) and neutral detergent fibre (NDF) (Table 4). The lowest CF content $(2.5 \%$ d.m. $)$ was obtained in cvs. Demanda and Martaínha, whilst the cvs. Longal, Rebordã and Zeive showed the highest $\mathrm{CF}$ content $(3.3 \%$ d.m.). These results were higher than those obtained by McCarthy and Meredith (1988) for the European chestnut (1.4\% d.m.) but similar to the values reported by Pereira-Lorenzo et al. (2005), which found positive correlations between ADF and CF, as in our study (Table 6). Cv. Demanda showed the lowest values of $\mathrm{ADF}(1.9 \%$ d.m.) and $\mathrm{NDF}(13.8 \%$ d.m. $)$, whilst the cv. Longal showed the highest ADF value (3.2\% d.m.) and cv. Rebordã had the highest NDF ( $24.4 \%$ d.m.) content. These values were similar to those reported by other researches (Ferreira-Cardoso, 2000; Pereira-Lorenzo et al., 2005). Salas-Salvadó and Megias (2005) indicated that nuts contain significant amounts of fibre compared to fresh fruits and green vegetables. Part of the positive nutritional effects of chestnuts is based on its fibre content, which have been associated with beneficial effects on human health and are sometimes considered to be useful for the prevention of obesity due to induction of a good intestine digestion (Wisker, Daniel, \& Felddheim, 1996).

\subsection{Free $\alpha$-amino acids}

The total amino acid profiles of the chestnuts (Table 5)

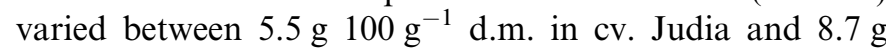
$100 \mathrm{~g}^{-1}$ d.m. in cv. Demanda, which also showed the highest value for crude protein content (Table 2). Regarding the total essential amino acids, the concentration ranged from

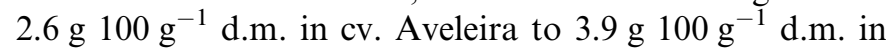
cv. Demanda. All cultivars from PDO 'Soutos da Lapa', Demanda, Longal and Martaínha, showed the best favourable amino acids profiles, which probably indicate that the environmental conditions affect nutritional composition. Gomes and Rosa (2000) and Alasalvar et al. (2003)

Table 4

Fibre content of the eight chestnut cultivars ( $\%$ d.m.)

\begin{tabular}{|c|c|c|c|c|}
\hline $\mathrm{PDO}$ & Cultivar & Crude fibre & $\mathrm{ADF}$ & NDF \\
\hline 'Padrela' & Judia & $3.13 \pm 0.15 b c$ & $3.07 \pm 0.17 \mathrm{e}$ & $19.4 \pm 0.1 \mathrm{c}$ \\
\hline 'Soutos da Lapa' & $\begin{array}{l}\text { Demanda } \\
\text { Longal } \\
\text { Martaínha }\end{array}$ & $\begin{array}{l}2.50 \pm 0.27 \mathrm{a} \\
3.33 \pm 0.21 \mathrm{c} \\
2.50 \pm 0.10 \mathrm{a}\end{array}$ & $\begin{array}{l}1.89 \pm 0.12 \mathrm{a} \\
3.15 \pm 0.02 \mathrm{e} \\
2.48 \pm 0.10 \mathrm{~b}\end{array}$ & $\begin{array}{l}13.8 \pm 0.3 \mathrm{a} \\
19.9 \pm 0.2 \mathrm{~d} \\
21.3 \pm 0.1 \mathrm{e}\end{array}$ \\
\hline 'Terra Fria' & $\begin{array}{l}\text { Aveleira } \\
\text { Rebordã } \\
\text { Trigueira } \\
\text { Zeive } \\
P\end{array}$ & $\begin{array}{l}2.63 \pm 0.06 \mathrm{a} \\
3.27 \pm 0.47 \mathrm{c} \\
2.83 \pm 0.15 \mathrm{ab} \\
3.33 \pm 0.06 \mathrm{c} \\
<0.001\end{array}$ & $\begin{array}{l}2.56 \pm 0.31 \mathrm{bc} \\
2.79 \pm 0.10 \mathrm{~cd} \\
2.90 \pm 0.06 \mathrm{de} \\
3.07 \pm 0.17 \mathrm{e} \\
<0.001\end{array}$ & $\begin{array}{l}21.8 \pm 0.6 \mathrm{f} \\
24.4 \pm 0.5 \mathrm{~g} \\
18.8 \pm 0.1 \mathrm{~b} \\
19.4 \pm 0.1 \mathrm{c} \\
<0.001\end{array}$ \\
\hline
\end{tabular}

Values are average of three individual samples per tree each analysed in triplicate \pm SD.

Different letters within one column denote statistically significant differences $(P<0.05)$ by ANOVA and Fisher's LSD test.

Statistical significance: ${ }^{*} P<0.05 ;{ }^{* *} P<0.01$; and ${ }^{* * *} P<0.001$ by Fisher's test. 
Table 5

Free $\alpha$-amino acid composition of the eight chestnut cultivars (g $100 \mathrm{~g}^{-1} \mathrm{~d} . \mathrm{m}$.)

\begin{tabular}{|c|c|c|c|c|c|c|c|c|c|}
\hline \multirow[t]{2}{*}{ Amino acid } & \multirow{2}{*}{$\begin{array}{l}\text { PDO 'Padrela' } \\
\text { Judia }\end{array}$} & \multicolumn{3}{|c|}{ PDO 'Soutos da Lapa' } & \multicolumn{4}{|c|}{ PDO 'Terra Fria' } & \multirow[t]{2}{*}{$P$} \\
\hline & & Demanda & Longal & Martaínha & Aveleira & Rebordã & Trigueira & Zeive & \\
\hline His & $0.59 \pm 0.04 \mathrm{~b}$ & $0.18 \pm 0.00 \mathrm{a}$ & $0.20 \pm 0.04 \mathrm{a}$ & $0.17 \pm 0.08 \mathrm{a}$ & $0.20 \pm 0.04 \mathrm{a}$ & $0.52 \pm 0.09 \mathrm{~b}$ & $0.23 \pm 0.00 \mathrm{a}$ & $0.56 \pm 0.00 \mathrm{~b}$ & $<0.001$ \\
\hline Ile & $0.19 \pm 0.00 \mathrm{a}$ & $0.48 \pm 0.04 \mathrm{~d}$ & $0.38 \pm 0.00 \mathrm{~cd}$ & $0.41 \pm 0.04 \mathrm{~cd}$ & $0.31 \pm 0.04 \mathrm{bc}$ & $0.37 \pm 0.01 \mathrm{c}$ & $0.37 \pm 0.04 \mathrm{c}$ & $0.22 \pm 0.04 \mathrm{ab}$ & $<0.05$ \\
\hline Leu & $0.45 \pm 0.03 \mathrm{ab}$ & $0.74 \pm 0.07 \mathrm{~d}$ & $0.56 \pm 0.04 \mathrm{c}$ & $0.60 \pm 0.04 \mathrm{c}$ & $0.40 \pm 0.03 \mathrm{a}$ & $0.57 \pm 0.11 \mathrm{bc}$ & $0.54 \pm 0.00 \mathrm{bc}$ & $0.48 \pm 0.00 \mathrm{abc}$ & $<0.05$ \\
\hline Lys & $0.40 \pm 0.04 \mathrm{ab}$ & $0.50 \pm 0.00 \mathrm{bc}$ & $0.59 \pm 0.08 \mathrm{c}$ & $0.58 \pm 0.00 \mathrm{c}$ & $0.32 \pm 0.08 \mathrm{a}$ & $0.36 \pm 0.12 \mathrm{ab}$ & $0.43 \pm 0.08 \mathrm{abc}$ & $0.48 \pm 0.07 \mathrm{bc}$ & $<0.001$ \\
\hline Met & $\mathrm{nd}^{\mathrm{a}}$ & nd & $0.08 \pm 0.04 \mathrm{c}$ & nd & $0.05 \pm 0.00 \mathrm{bc}$ & $0.03 \pm 0.04 \mathrm{ab}$ & nd & $0.05 \pm 0.00 \mathrm{bc}$ & $<0.05$ \\
\hline Phe & $0.18 \pm 0.00 \mathrm{a}$ & $0.38 \pm 0.09 \mathrm{c}$ & $0.24 \pm 0.00 \mathrm{ab}$ & $0.21 \pm 0.04 \mathrm{ab}$ & $0.21 \pm 0.04 \mathrm{ab}$ & $0.19 \pm 0.09 \mathrm{a}$ & $0.22 \pm 0.05 \mathrm{ab}$ & $0.33 \pm 0.04 \mathrm{bc}$ & $>0.05$ \\
\hline Thr & $0.20 \pm 0.04 \mathrm{a}$ & $0.36 \pm 0.00 \mathrm{~b}$ & $0.24 \pm 0.03 \mathrm{a}$ & $0.28 \pm 0.03 \mathrm{ab}$ & $0.19 \pm 0.03 \mathrm{a}$ & $0.23 \pm 0.09 \mathrm{a}$ & $0.20 \pm 0.03 \mathrm{a}$ & $0.24 \pm 0.09 \mathrm{a}$ & $>0.05$ \\
\hline Val & $0.28 \pm 0.04 \mathrm{a}$ & $0.47 \pm 0.04 \mathrm{c}$ & $0.42 \pm 0.00 \mathrm{bc}$ & $0.42 \pm 0.00 \mathrm{bc}$ & $0.44 \pm 0.03 \mathrm{c}$ & $0.40 \pm 0.06 \mathrm{bc}$ & $0.48 \pm 0.06 \mathrm{c}$ & $0.34 \pm 0.06 \mathrm{ab}$ & $<0.05$ \\
\hline Ser & $0.19 \pm 0.00 \mathrm{a}$ & $0.52 \pm 0.06 \mathrm{c}$ & $0.30 \pm 0.05 \mathrm{~b}$ & $0.31 \pm 0.05 \mathrm{~b}$ & $0.28 \pm 0.03 \mathrm{ab}$ & $0.26 \pm 0.08 \mathrm{ab}$ & $0.29 \pm 0.03 \mathrm{ab}$ & $0.27 \pm 0.06 \mathrm{ab}$ & $<0.05$ \\
\hline Tyr & $0.26 \pm 0.00 \mathrm{c}$ & $0.24 \pm 0.04 \mathrm{bc}$ & $0.07 \pm 0.00 \mathrm{a}$ & $0.17 \pm 0.05 \mathrm{~b}$ & $0.19 \pm 0.00 \mathrm{bc}$ & $0.17 \pm 0.04 \mathrm{~b}$ & $0.24 \pm 0.05 \mathrm{bc}$ & $0.23 \pm 0.04 \mathrm{bc}$ & $<0.05$ \\
\hline Ala & $0.60 \pm 0.02 \mathrm{~b}$ & $0.74 \pm 0.04 \mathrm{c}$ & $0.57 \pm 0.02 \mathrm{~b}$ & $0.60 \pm 0.02 \mathrm{~b}$ & $0.45 \pm 0.04 \mathrm{a}$ & $0.58 \pm .07 \mathrm{~b}$ & $0.65 \pm 0.02 \mathrm{bc}$ & $0.63 \pm 0.07 \mathrm{~b}$ & $<0.05$ \\
\hline Arg & $0.25 \pm 0.00 \mathrm{ab}$ & $0.69 \pm 0.04 \mathrm{~cd}$ & $0.79 \pm 0.04 \mathrm{~d}$ & $0.47 \pm 0.04 \mathrm{bc}$ & $1.16 \pm 0.05 \mathrm{e}$ & $0.40 \pm 0.04 \mathrm{ab}$ & $0.36 \pm 0.05 \mathrm{ab}$ & $0.22 \pm 0.04 \mathrm{a}$ & $<0.001$ \\
\hline Asp & $0.85 \pm 0.04 \mathrm{bc}$ & $1.41 \pm 0.07 \mathrm{e}$ & $1.35 \pm 0.00 \mathrm{e}$ & $1.13 \pm 0.03 \mathrm{~d}$ & $0.70 \pm 0.04 \mathrm{a}$ & $0.92 \pm 0.11 \mathrm{bc}$ & $0.82 \pm 0.04 \mathrm{ab}$ & $0.95 \pm 0.04 \mathrm{c}$ & $<0.001$ \\
\hline Cys & nd & $0.05 \pm 0.00 \mathrm{~b}$ & $0.04 \pm 0.00 \mathrm{~b}$ & nd & $0.04 \pm 0.00 \mathrm{~b}$ & $0.05 \pm 0.00 \mathrm{~b}$ & $0.03 \pm 0.04 \mathrm{ab}$ & $0.02 \pm 0.03 \mathrm{ab}$ & $>0.05$ \\
\hline Glu & $0.77 \pm 0.04 \mathrm{ab}$ & $1.03 \pm 0.04 \mathrm{~b}$ & $0.61 \pm 0.11 \mathrm{a}$ & $0.80 \pm 0.08 \mathrm{ab}$ & $0.64 \pm 0.08 \mathrm{a}$ & $0.63 \pm 0.20 \mathrm{a}$ & $0.74 \pm 0.04 \mathrm{a}$ & $0.86 \pm 0.23 \mathrm{ab}$ & $>0.05$ \\
\hline Gly & $0.36 \pm 0.04 \mathrm{ab}$ & $0.53 \pm 0.02 \mathrm{~d}$ & $0.30 \pm 0.04 \mathrm{a}$ & $0.44 \pm 0.04 \mathrm{bcd}$ & $0.30 \pm 0.04 \mathrm{a}$ & $0.36 \pm 0.00 \mathrm{abc}$ & $0.46 \pm 0.06 \mathrm{~cd}$ & $0.39 \pm 0.08 \mathrm{abc}$ & $<0.05$ \\
\hline Pro & nd & $0.35 \pm 0.06 \mathrm{~d}$ & $0.27 \pm 0.03 \mathrm{~cd}$ & $0.29 \pm 0.00 \mathrm{~cd}$ & $0.21 \pm 0.00 \mathrm{bc}$ & $0.15 \pm 0.03 \mathrm{~b}$ & $0.24 \pm 0.09 \mathrm{bc}$ & nd & $<0.001$ \\
\hline $\begin{array}{l}\text { Total } \\
\text { essential } \\
\text { amino } \\
\text { acids }\end{array}$ & $2.73 \pm 0.49 \mathrm{ab}$ & $3.86 \pm 0.26 \mathrm{c}$ & $3.12 \pm 0.04 \mathrm{~b}$ & $3.13 \pm 0.16 b$ & $2.58 \pm 0.25 \mathrm{a}$ & $3.07 \pm 0.30 \mathrm{~b}$ & $2.99 \pm 0.11 \mathrm{ab}$ & $3.19 \pm 0.26 \mathrm{~b}$ & $<0.05$ \\
\hline $\begin{array}{l}\text { Total amino } \\
\text { acids }\end{array}$ & $5.54 \pm 0.03 \mathrm{a}$ & $8.65 \pm 0.40 \mathrm{c}$ & $7.04 \pm 0.14 b$ & $6.84 \pm 0.27 b$ & $6.06 \pm 0.32 \mathrm{ab}$ & $6.15 \pm 0.98 \mathrm{ab}$ & $6.27 \pm 0.02 \mathrm{ab}$ & $6.25 \pm 0.74 \mathrm{ab}$ & $<0.05$ \\
\hline
\end{tabular}

Values are average of three individual samples per tree each analysed in triplicate \pm SD.

Different letters within one column denote statistically significant differences $(P<0.05)$ by ANOVA and Fisher's LSD test.

Statistical significance: ${ }^{*} P<0.05 ;{ }^{* *} P<0.01$; and ${ }^{* * *} P<0.001$ by Fisher's test.

${ }^{\text {a }}$ nd - not detected.

considered that the content of amino acids in broccoli and hazelnuts, respectively, also depends on the climatic conditions.

Table 5 shows a total of seventeen amino acids identified in the eight cultivars, namely cysteine (Cys), proline (Pro), L-alanine (Ala), L-aspartic acid (Asp), glycine (Gly), L-glutamic acid (Glu), arginine (Arg) and the essential amino acids: isoleucine (Ile), leucine (Leu), lysine (Lys), L-histidine (His), L-methionine (Met), L-threonine (Thr), L-phenylalanine (Phe), L-tyrosine (Tyr), L-serine (Ser) and L-valine (Val). The amino acid profile was dominated by Asp (1.0 g $100 \mathrm{~g}^{-1}$ d.m.), which resulted from the conversion of asparagine (Desmaison, Marcher, \& Tixier, 1984). Other important amino acids were Glu $\left(0.8 \mathrm{~g} 100 \mathrm{~g}^{-1}\right.$ d.m. $)$, which resulted from glutamine, followed by Leu and Ala $(0.6 \mathrm{~g}$ $100 \mathrm{~g}^{-1}$ d.m.) and $\operatorname{Arg}\left(0.5 \mathrm{~g} 100 \mathrm{~g}^{-1}\right.$ d.m.). These results are in accordance with Meredith, McCarthy, and Leffler (1988) for several Italian, Chinese and American cultivars. Moreover, Desmaison and Tixier (1984) referred the highest concentration of the amino acid asparagine in C. sativa, $C$. crenata and C. crenata $\times$ C. sativa. Nevertheless, in C. mollissima, Glu was presented in high concentration. These five amino acids constituted $50 \%$ of the total free $\alpha$-amino acids . In general, chestnuts are a good source of these compounds, however, amino acids profiles are not well balanced, with certain essential amino acids occurring in limiting concentration when compared to FAO (1990) recommended levels.
According to Alasalvar, Shahidi, Liyanapathirana, and Ohshima (2003) plant proteins (including nuts) are often called incomplete proteins, because they generally do not have enough of one or more of the essential amino acids. Others essential amino acids that were identified to occur in most limiting concentrations were Met $\left(0.001 \mathrm{~g}^{100 \mathrm{~g}^{-1}}\right.$

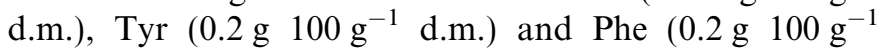
d.m.). The sulfur-containing amino acids (Met and Cys) were present in the lowest concentrations.

The correlation matrix (Table 6) shows some important relationships between the chemical components analysed. For instance total amino acids were correlated positively with crude protein $(r=0.875, P<0.001)$, but negatively correlated with $\mathrm{ADF}(r=-0.810, P<0.001)$ and $\mathrm{NDF}$ $(r=-0.699, P<0.01)$. Crude fat was negatively correlated with NDF $(r=-0.791, P<0.001)$. In addition, $\mathrm{K}$ was positively correlated with crude fibre $(r=0.734, P<0.001)$ and ADF $(r=0.816, P<0.001), P$ was negatively correlated with $\operatorname{NDF}(r=-0.913, P<0.001)$ and positively with crude protein $(r=0.757, P<0.001)$, and $\mathrm{Mg}$ was negatively correlated with $\operatorname{ADF}(r=-0.790, P<0.001)$. According to Pereira-Lorenzo et al. (2005), the correlations between minerals and environment was low and not significant, indicating that differences found among the 47 Spanish cultivars were due to genetic differences.

Table 7 shows the coefficients of variation of the nutritional parameters of the chestnuts studied, obtained from 
Table 6

Correlations (linear correlation coefficients) between chemical parameters of the eight chestnut cultivars

\begin{tabular}{|c|c|c|c|c|c|c|c|c|c|}
\hline Parameter & Total amino acids & Moisture & Crude fat & Crude protein & Starch & $\begin{array}{l}\text { Reductor } \\
\text { sugars }\end{array}$ & $\begin{array}{l}\text { Crude } \\
\text { fibre }\end{array}$ & NDF & $\mathrm{ADF}$ \\
\hline \multicolumn{10}{|l|}{ Total amino acids } \\
\hline Moisture & 0.402 & & & & & & & & \\
\hline Crude protein & $0.875^{* * *}$ & 0.439 & 0.123 & & & & & & \\
\hline Starch & -0.235 & $-0.539^{*}$ & 0.056 & -0.4476 & & & & & \\
\hline Sugar reductors & -0.124 & 0.199 & 0.105 & 0.149 & -0.063 & & & & \\
\hline $\mathrm{ADF}$ & $-0.810^{* * *}$ & -0.381 & -0.381 & $-0.559^{*}$ & 0.314 & $0.568^{*}$ & $0.712^{* * *}$ & 0.434 & \\
\hline $\mathrm{P}$ & $0.642^{* *}$ & $0.722^{* * *}$ & $0.596^{*}$ & $0.757^{* * *}$ & -0.319 & 0.489 & -0.044 & $-0.913^{* * *}$ & -0.289 \\
\hline $\mathrm{Mg}$ & $0.691^{* *}$ & 0.050 & -0.001 & $0.620^{*}$ & -0.148 & $-0.591^{*}$ & -0.227 & -0.217 & $-0.790^{* * *}$ \\
\hline $\mathrm{K}$ & $-0.649^{* *}$ & -0.562 & -0.283 & -0.4429 & $0.557^{*}$ & 0.363 & $0.734^{* * *}$ & 0.308 & $0.816^{* * *}$ \\
\hline $\mathrm{Ca}$ & -0.050 & $-0.879^{* * *}$ & $-0.547^{*}$ & -0.030 & 0.495 & -0.125 & 0.285 & 0.324 & 0.246 \\
\hline
\end{tabular}

Statistical significance: ${ }^{*} P<0.05 ;{ }^{* *} P<0.01$; and ${ }^{* * *} P<0.001$ by Fisher's test.

Table 7

Coefficients of variation $\left[(\mathrm{SD} / \mathrm{mean})^{*} 100\right]$ of main parameters analysed

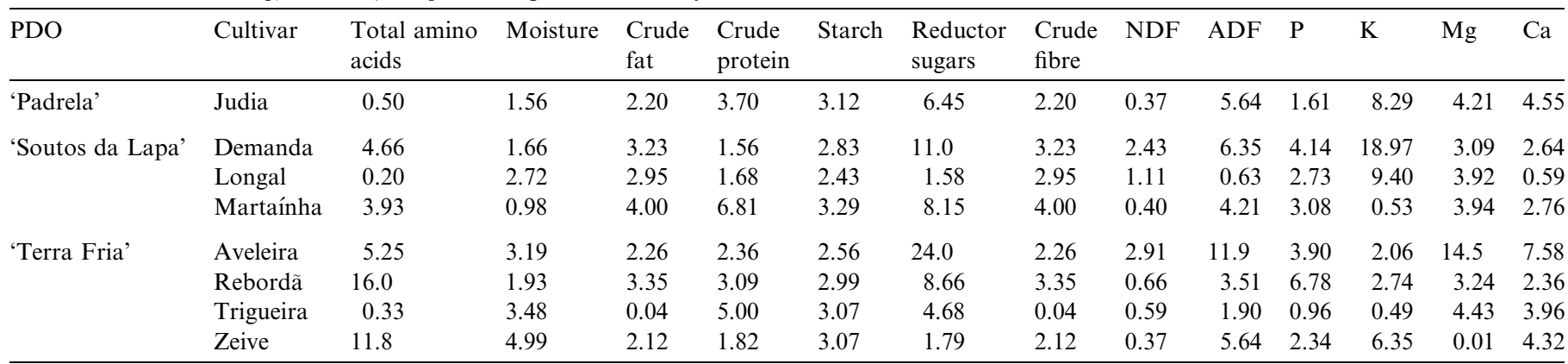

different trees, to verify the intravarietal homogeneity. All of the coefficients of variation of the cvs. Longal, Trigueira and Judía were lower than $12 \%$, outstanding their homogeneity. Chestnuts from cvs. Aveleira and Rebordã showed just one coefficient of variation higher than $20 \%$, reductor sugars and non-essential amino acids, respectively.

In order to establish the relationships between the different variables and to detect the most important causes of variability, PCA was applied to the total amino acids, crude protein, crude fat, starch, reductor sugars, crude fibre, NDF, ADF, minerals and fruit weight for the eight cultivars (Fig. 1). Three principal components (PC) were obtained, accounting for $77 \%$ of the total variance (TV). PC 1 explained $41 \%$ of the TV and the parameters that correlated best with this PC were ADF (0.871), total amino acids $(-0.869)$, crude fibre $(0.762)$ and minerals $(0.710)$. The parameters best correlated with PC2 (that accounted for $21 \%$ of TV) were reductor sugars (0.837) and NDF $(-0.677)$ and with PC3 (that accounted for $15 \%$ of TV) were crude fat $(0.730)$ and starch $(0.603)$. Fig. 1 shows the distribution of the samples in the plane defined by $\mathrm{PC} 1$ and $\mathrm{PC} 2$ and $\mathrm{PC} 1$ and PC3. Two groups were defined
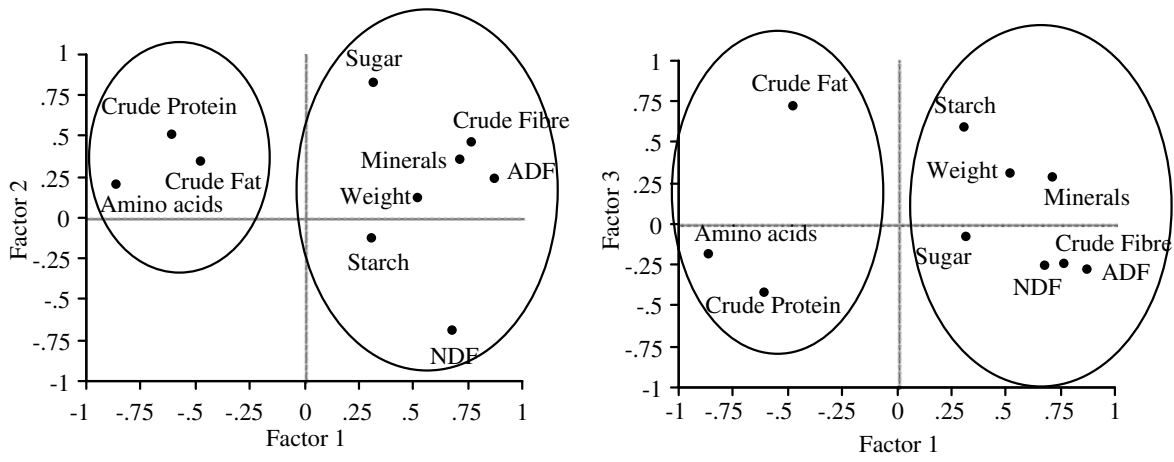

Fig. 1. Principal component analysis plot for nutritional parameters of the eight chestnut cultivars. 
according to the position of each sample. The crude protein, crude fat and total amino acids showed similar variation in relation to the $\mathrm{PCl}$ whilst for starch, reductor sugars, minerals, fruit weight, crude fibre, ADF and NDF showed an inverse variation.

Finally, this study confirmed that chestnuts present higher moisture content, high levels of starch and low fat content, which makes it an interesting healthy food. In addition, this fruit contains significant amounts of fibre with beneficial effects on human health and these are sometimes considered to be useful for the prevention of obesity due to induced good intestine digestion. Regarding mineral content, chestnuts are a good source of $\mathrm{K}, \mathrm{Mg}, \mathrm{Fe}, \mathrm{Mn}$ and $\mathrm{Cu}$. The amino acid profile is dominated by L-aspartic acid, followed by L-glutamic acid, Leucine, L-alanine and Arginine.

The differences found among the studied cultivars in nutrient composition may reflect genetic factors and environmental conditions. This information could be useful for the market and consumers. Thus, the chestnuts from cv. Zeive (PDO 'Terra Fria') are appropriate for flour production due to their high starch content. Cv. Rebordã (PDO 'Terra Fria') nuts presented low moisture content, which may increase their postharvest storage. Cv. Demanda nuts with a low value of NDF are more desirable to get good intestine digestion. Also, other studies with Portuguese cultivars (Borges et al., 2006) identified two cultivars with potential health effects: cv. Lada (PDO 'Padrela') with consistently high linoleic acid content and cv. Aveleira (PDO 'Terra Fria') had a high proportion of unsaturated fatty acids.

\section{References}

Alasalvar, C., Shahidi, F., Liyanapathirana, C. M., \& Ohshima, T. (2003). Turkish tombul hazelnut (Corylus avellana L.). 1. Compositional characteristics. Journal of Agricultural and Food Chemistry, 51, 3790-3796.

AOAC (1990). Official methods of analysis (15th ed.). Washington, DC: Association of Official Analytical Chemists.

AOAC (2000). Official methods of analysis (17th ed.). Washington, DC: Association of Official Analytical Chemists.

Bassi, D., \& Marangoni, B. (1984). Contributo allo studio varietale del castagno da fruto (C. sativa Mill.): caratteri biometrici e analisi chimico-fisiche dei frutti. Rivista di Frutticoltura, 6, 43-46.

Blomhoff, R., Carlsen, M. H., Andersen, L. F., \& Jacobs, D. R. (2006). Health benefits of nuts: potential role of antioxidants. British Journal of Nutrition, 96(2), S52-S60.

BOE (1995). R.D. 2257/1994 de 25-II-94. B.O.E. no. 52 de 02/03/1995, 52, 7161-7237.

Borges, O., Carvalho, J., Correia, P., \& Silva, A. P. (2006). Lipid and fatty acid profile of Castanea sativa Mill. nuts of seventeen native Portuguese cultivars. Journal of Food Composition and Analysis, 20, $80-89$.

De La Montaña Míguelez, J., Míguez Bernárdez, M., \& Garcia Queijeiro, J. M. (2004). Composition of varieties of chestnuts from Galicia (Spain). Food Chemistry, 84(3), 401-404.

Demiate, I. M., Oetterer, M., \& Wosiacki, G. (2001). Characterization of chestnut (Castanea sativa Mill) starch for industrial utilization. Brazilian Archives of Biology and Technology, 44(1), 69-78.

Desmaison, A. M., \& Adrian, J. (1986). La place de la châtaigne en alimentation. Medicine et Nutrition, 22(3), 174-180.
Desmaison, A. M., Marcher, H. M., \& Tixier, M. (1984). Changes in the free and total amino acid composition of ripening chestnut seeds. Phytochemistry, 23(11), 2453-2456.

Desmaison, A. M., \& Tixier, M. (1984). Acides aminés libres de châtaigne provenant de Castanea sativa Mill., Castanea crenata Sieb at Zucc., Castanea molissima Blume et d' hybrides: Castanea crenata $\times$ sativa. Annales des Pharmaceuriques. Française, 42(4), 353-357.

Diehl, J. F. (2002). Nuts shown to offer health benefits. International News on Fats, Oils and Related Materials, 13(2), 134-138.

Ertürk, U., Cevriye, M., \& Arif, S. (2006). Chemical composition of fruits of some important chestnut cultivars. Agriculture, Agribusiness and Biotechnology, 49(2), 183-188.

FAO (1990). Consulted online at: http://www.fao.org/waicent/portal/ statistics_en.asp.

FAO (1998). World reference base for soil resources. Rome: FAO.

Ferreira-Cardoso, J. V. (2000). Caracterização e valorização do fruto de Castanea sativa Mill. Composição química, valor nutritivo e efeito da sua utilização na engorda de porcos Duroc. PhD Tesis, UTAD, Portugal.

Ferreira-Cardoso, J. V., Rodrigues, L., Gomes, E. F., Sequeira, C. A., \& Torres-Perreira, J. M. G. (1999). Lipid composition of Castanea sativa Mill. fruits of some native Portuguese cultivars. Acta Horticulturae, 494, 138-166.

Garcia, W. J., \& Wolf, M. J. (1972). Polarimetric determination of starch in corn with dimethyl sulfoxide as a solvent. Cereal Chemistry, 49, 298-306.

Gomes, H. M., \& Rosa, E. (2000). Free amino acid composition in primary and secondary inflorescences of 11 broccoli (Brassica oleracea var italica) cultivars and its variation between growing seasons. Journal of the Science of Food and Agriculture, 81, 295-299.

Iqbal, A., Khalil, I. A., Ateeq, N., \& Khan, M. S. (2006). Nutritional quality of important food legumes. Food Chemistry, 97, 331-335.

Künsch, U., Scharer, H., Conedera, M., Sassella, A., Jermini, M., \& Jelmini, G. (1999). Quality assessment of chestnut fruits. Acta Horticulturae, 494, 119-127.

McCarthy, M. A., \& Meredith, F. I. (1988). Nutrient data on chestnuts consumed in the United States. Economic Botany, 42(1), 29-36.

Meredith, F. I., McCarthy, M. A., \& Leffler, R. (1988). Amino acid concentrations and comparison of different hydrolysis procedures for American and foreign chestnuts. Journal of Agricultural and Food Chemistry, 36(6), 1172-1175.

Parcerisa, J., Rafeces, M., Castellote, A. I., Codony, R., Farran, A., \& Garcia, J. (1995). Influence of variety and geographical origin on the lipid fraction of hazelnuts (Corylus avellana L.) from Spain: III. Oil stability, tocopherol content and some mineral contents. Food Chemistry, 53, 71-74.

Pereira-Lorenzo, S., Ramos-Cabrer, A. M., Díaz-Hernández, M. B., Ciordia-Ara, M., \& Rios-Mesa, D. (2005). Chemical composition of chestnut cultivars from Spain. Scientia Horticulturae, 107(3), 306-314.

Portela, E., Ferreira-Cardoso, J. V., Reboredo, M., \& Pimentel-Pereira, M. J. (1999). Influence of magnesium deficiency on chestnut (Castanea sativa Mill.) yield and nut quality. In D. Anaç \& P. Martin-Prével (Eds.), Improved crop quality by nutrient management. Dordrecht, The Netherlands: Kluwer Academic Publishers.

Sabaté, J., Radak, T., \& Brown, J. Jr., (2000). The role of nuts in cardiovascular disease prevention. In R. Wildman (Ed.), Handbook of nutraceuticals and functional foods (pp. 261-267). London: CRC Press.

Salas-Salvadó, J., \& Megias, I. (2005). Health and tree nuts: scientific evidence of disease prevence. Acta Horticulturae, 686, 507-513.

Senter, S. D., Payne, J. A., Miller, G., \& Anagnostakis, S. L. (1994). Comparison of total lipids, fatty acids, sugars and nonvolatile acids in nuts from four Castanea species. Journal of the Science of Food and Agriculture, 65(2), 223-227.

Stamler, J. (1994). Assessing diets to improve world health: nutritional research on disease causation in populations. American Journal of Clinical Nutrition, 59, 146S-156S.

Stein, W. H., \& Moore, S. (1978). Amino acid determination, methods and techniques (2nd ed.). S. Blackburn. Marcel Dekker Inc. 
Üstün, N., Tosun, Y., \& Serdar, Ü. (1999). Technological properties of chestnut varieties grown in Erfelek district of Sinopy city. Acta Horticulturae, 494, 107-110.

Van Soest, P. J., \& Wine, R. H. (1967). Use of detergents in the analysis of fibrous feed. IV. Determination of plant cell-wall constituents. Journal of International Association of Official Analytical, 50, 50-55.
Vaughan, J. G., \& Geissler, C. A. (1997). The new Oxford book of food plants. New York: Oxford University Press.

Wisker, E., Daniel, M., \& Felddheim, W. (1996). Particle size of whole meal rye bread does not affect the digestibility of macro nutrients and non-starch polysaccharides and the energy value of dietary fiber in humans. Journal of the Science of Food and Agriculture, 70, 327-333. 